\title{
REACHING, ENGAGING AND BONDING WITH VOTERS ON SOCIAL MEDIA: THE CASE OF 2014/2015 CROATIAN PRESIDENTIAL ELECTIONS
}

\section{Dubravka Sinčić Ćorić :: Ružica Brečić :: Maja Šimunjak}

IZVORNI ZNANSTVENI RAD / DOI: 10.20901/ms.8.16.5 / PRIMLJENO: 28.03.2017.

ABSTRACT This paper examines the ways in which presidential candidates utilise social media as a tool in their election campaigns in order to democratise politics and political representation. The study is based on a content analysis of statements published on the official Facebook and Twitter pages of candidates in the 2014/2015 Croatian presidential elections. The results show that candidates did not use social media to reach, engage and form stronger bonds with potential voters. By failing to do so, they have missed an opportunity to bring disenchanted voters back into the political arena and potentially increase the legitimacy of the democratic processes.

KEY WORDS

SOCIAL MEDIA, POLITICAL CAMPAIGN, PRESIDENTIAL ELECTIONS, DEMOCRATISATION OF POLITICS

Authors Note

Dubravka Sinčić Ćorić :: University of Zagreb, Faculty of Economics and Business, Croatia :: dsincic@efzg.hr

Ružica Brečić :: University of Zagreb, Faculty of Economics and Business, Croatia :: rbrecic@efzg.hr Maja Šimunjak :: Middlesex University London, Faculty of Arts and Creative Industries, United Kingdom :: m.simunjak@mdx.ac.uk 


\section{INTRODUCTION}

Social scientists in the past, contrary to early political observers, tended to downplay the effects of new technologies - at that time referring to radio, newsreels and television - on electoral campaigns (Hong and Nadler, 2012). However, since the 1970s, numerous studies have shown that the content of news stories and campaign advertisements can affect public opinion towards government policies. Later research has confirmed this, by showing that relevant "cues" and "information shortcuts" in the social and political environment can influence voters, especially towards the candidates whose names or political parties are most cognitively accessible (Hong and Nadler, 2012: 456).

The rise of the internet, bringing with it social media platforms such as Facebook and Twitter, has provoked further debate. Se Jung Park and colleagues (2016) presented a study with mixed results, suggesting that how social media is used, and by whom, may determine social media's function as a political discussion platform and also determine the platform's predictive power to influence offline politics.

There is a growing interest in the utilisation of new media in electoral campaigning (Larsson and Moe, 2012). Past research consists mostly of nationally based case studies (e.g. Baxter and Marcela, 2012; Gibson, 2015; Graham et al., 2013 (all cases of the UK); Bruns and Highfield, 2013 (Australia); Carlisle and Patton, 2013; Nielsen and Vaccari, 2013; Murthy and Petto, 2015; Groshek and Koc-Michalska, 2017 (all cases of the U.S.); Jungherr, 2012 (Germany), Larsson and Moe, 2013 (Denmark); Strandberg, 2013 (Finland); Vaccari et al., 2013 (Italy); Kalsnes et al., 2014; Larsson, 2015 (both cases of Norway), Ross et al., 2015 (New Zealand); Ahmed et al., 2016 (India)). Most of these studies reflect upon economically developed, highly wired, or politically stable societies, whilst there is a lack of studies concerning young democracies and transitional countries. Rarely is there evidence of exploration into the utilisation of social media in more diverse contexts. For instance, Milica Vučković and Domagoj Bebić (2013) analysed how city mayors in Central and South-Eastern Europe, specifically Bulgaria, Croatia, Hungary, Macedonia and Slovenia, utilised Facebook during their electoral campaigns, and Marton Bene (2017) explored viral posts during the Hungarian general election campaign in 2014. These Central Eastern European countries can also make an important contribution to research, since they are characterised by low voter turnout, the lack of voters' engagement in the political process, and a distrust in political institutions.

Darren Lilleker and colleagues (2015) found that social media, Facebook in particular, is considered by party strategists a standard feature of campaigning in European democracies, and particularly important in Central Eastern European countries where party systems are weak and still developing. Given also that within the Croatian political arena 2014, there was a climate of high distrust and low political engagement amongst citizens (European Commission, 2014; Ukpolitical.info, n.d.), it is important to examine whether politicians utilised social media to its full potential. In consideration of all of this, the goal of this paper is to analyse how Croatian presidential candidates used social 
media as a tool to reach, engage and create bonds with voters during the 2014/2015 Croatian presidential elections.

\section{SOCIAL MEDIA AS AN OPPORTUNITY FOR ENGAGEMENT BETWEEN POLITICIANS AND CITIZENS}

The successful utilisation of Facebook throughout Obama's 2008 campaign convinced many politicians to take Facebook more seriously as a campaign tool. However, in spite of Facebook's contribution, clear evidence of its efficiency is still missing. When Karen Ross, Susan Fountaine and Margie Comrie (2015: 252) attempted to prove the effectiveness of online campaigning, including social media, they detected that party websites, blogs, Facebook profiles and Twitter accounts were merely "hi-tech ways of transmitting old-tech messages". Karen Ross and Tobias Bürger (2014) similarly claim that most politicians see social media communication as a one-way street, so they use a monologic approach, rarely getting involved in comment threads, or instigating dialogue with their voters on social media. Digital communication technology enables greater interaction between campaign staff and citizens, and amongst citizens themselves, however, political campaigns tend to limit those interactions and favour the role of public relations in political campaigns (Stromer-Galley, 2014: 172). In addition, studies have shown that politicians tend to avoid actual dialogue and remain reluctant to fully engage with citizens on social media (e.g. Sweetser and Lariscy, 2008; Nielsen, 2011; Macnamara and Kenning, 2013; Ross et al., 2015). Darren Lilleker, Mark Pack and Nigel Jackson (2010: 106) also point out that although Web 2.0 applications provide the "architecture of participation", political elites are reluctant to utilise their maximum "transformative potential". Contrary to this, it is only by utilising social media (and its capacity for interactivity) to the fullest, that a "real shift in politicalpublic communication" would be possible (Ross et al., 2015: 252).

Furthermore, Sonja Utz (2009) argues that social media presents an opportunity for political engagement. She refers particularly to young people and claims that they may be unintentionally "exposed to candidate profiles and fresh political viewpoints" whilst surfing the net (Utz, 2009: 223). Additionally, members of different social networks will be more likely exposed to "conflicting political viewpoints, which benefits democracy" (Ibid.). Being online enables politicians to convey their desired message through personal and individual channels such as social networks or microblogs. In that sense, social media represent semi-public, semi-private spaces for self-representation, where borders between offline personal and online-mediated relations are blurred (Enli and Thumim, 2012). Social media facilitates sharing, connecting and storytelling, enabling candidates to humanise their image and get closer to their voters. Furthermore, through the utilisation of social media, candidates have the opportunity to share their opinions with voters and listen to their followers' comments. They can add value to the social network community by launching interesting questions and by generating discussion on certain issues, or adding links, images, and information of interests (Zamora Medina and Zurutuza Munoz, 2014). 


\section{CONCEPTUAL FRAMEWORK}

This paper addresses the gap identified in the existing literature by describing how presidential candidates utilise social media throughout the elections of a young Central Eastern European democracy. The starting premise is that (1) candidates utilise social media to reach voters online, that (2) candidates utilise social media to engage with voters, and that (3) candidates utilise social media to create bonds with voters. Hence, this paper focuses on analysing the ways in which social media have (or have not) been used in political campaigns for the democratisation of politics, and does not discuss the marketing potential of social media in election campaigns nor the ability of social media to influence election results. Although much has been said about the possibilities of using social media in politics, an integrative theoretical model has not yet been proposed within the existing literature. Therefore, a combination of techniques that politicians can employ to maximise the potential of social media has been drawn from the literature and from previous research (Ross et al., 2015). This serves as a conceptual framework in this study. The proposed list of techniques is not all-inclusive, but considered the most relevant for this research.

\section{Reaching Voters via Social Media}

In order to examine the extent to which candidates use social media to reach voters, this study examines candidates' (1) use of hashtags and tagged accounts and (2) sharing of others' content.

Hashtags on Twitter and tagged accounts on Facebook are the most common ways of categorising content on social networks, and serves the purpose of making one's tweet/ post more easily discoverable. By using hashtags/tagged accounts, politicians can help potential voters to find them on social media and better express themes and interests that they want to promote. Similarly, they may tap into others' networks by retweeting/ sharing content from other social media accounts. This not only demonstrates the power of their networks and competence in using social media, but it also makes them visible to potential new voters who are connected via shared contacts. Indeed, some scholars argue that modern technology, particularly social networks, have a significant potential to expose citizens to a wider range of perspectives, ideas, and viewpoints (Bozdag and van den Hoven, 2015). In the context of election campaigns, this would mean that citizens who are not particularly interested in politics, or are interested in a particular political option, might be 'accidentally' exposed to diverse political candidates and their ideas. However, others argue that this 'accidental exposure' is very limited and that actually social media users operate in 'filter bubbles' and 'echo chambers' created by social media's algorithms, which serve to provide users with content they might be interested in based on the preferences they have shown in the past (Bozdag and van den Hoven, 2015; Spohr, 2017). If this is the case, then this might hinder politicians' attempts at reaching citizens with a limited interest in politics, those undecided or those with other political values. Research into this phenomenon shows a mixed picture. For example, Seth Flaxman, Sharad Goel and Justin Rao (2016: 298) in their study of 50,000 US-located users found evidence for both sides of the debate, but also argue that the effects are "modest". 
This might give hope to politicians aiming to reach wider audiences on social media, as there appears to be opportunities for them to "help raise political awareness and make citizens more interested in politics as well as getting them to debate political issues they have heard about online" (Gustafsson, 2012: 1). Hence, attempts at reaching voters via social media can help voters hear a wider range of political arguments, and consequently, aid in the process of making better-informed choices at polling stations.

\section{Utilising Social Media by Engaging Voters}

To analyse the ways in which candidates engage with voters via social media, the study focuses on candidates' (1) calls for action, (2) posing of questions, (3) participation in the comments section, and (4) attaching multimedia materials to social media posts.

One of the most powerful aspects of social media is "to enable access to cascading networks of potential new audiences and new supporters" (Ross et al., 2015: 267).

Jennifer Stromer-Galley (2014: 169) is of the opinion that campaigns are going in the direction of ever more data driven decision-making and organising in political campaigns. As she puts it, this encompasses new opportunities to control interactivity by targeting messages to audiences, looking for ways to move them up the activity ladder from having a casual interest to voting, to being a team leader. Furthermore, Stromer-Galley (2014: 174) explains that campaigns attempt to harness the power of two-step flow in that voters do not passively watch political ads, as they would have in the 1980 s and earlier, but in that they actively get out and talk to their neighbours, call undecided voters in a nearby state, or share on Facebook enthusiasm for a new campaign, such as generated YouTube video. This outlines clearly why it is that politicians should actively ask their followers/friends to share posts with their own networks and online friendship groups.

Additionally, politicians may engage with voters via social media, by opening dialogue and building relationships with followers by asking questions and prompting reactions and opinions on relevant topics. This interactive, dialogic element of political communication on social media can be seen as fully developed only if the politicians also participate in the discussions, usually in the comments sections. They can engage in discussions with voters and in that way, contribute to fulfilling the deliberative ideal of social media, which is seen as a platform that offers "new possibilities for online political conversations between citizens and politicians" (Sørensen, 2016: 664). Indeed, conversations between political candidates and voters on social media may be seen as a step forward to democratising politics, allowing citizens to directly engage in discussions with those who aim to represent them, and ultimately lead to the "revitalisation of the public sphere" (Sørensen, 2016: 665; see also Coleman, 2005; Jensen, 2011; Papacharissi, 2002).

Finally, politicians may also aim to attach multimedia content to their social media posts, since data from social networks shows that posts with multimedia content significantly increases user engagement (Blog.twitter.com, 2015). 


\section{Creating Bonds with Voters}

Finally, to establish the ways in which candidates use social media to bond with voters, the research looks at the (5) focus of candidates' statements, (6) the extent to which information from private life is shared, and (7) the language that candidates use on social media.

One of the most important benefits of social media within the political arena, is that politicians are able to use it to communicate their political viewpoints to voters in a controlled and unobstructed way. Social networks can help politicians forge a closer personal bond with voters (Enli and Skogerbø, 2013; Larsson, 2015; Savulescu and Vitelar, 2012), and act as a supplement to politicians' political images by revealing private personae, rather than repeating the information from the political sphere (Zamora Medina and Zurutuza Munoz, 2014). 'Going personal' is not a new technique in political communication, since it has been claimed for some time that "politicians need to be able to operate smoothly in personal discourse in order to construct themselves as likeable individuals, which is a necessary part of the political persona" (Van Zoonen and Holtz-Bacha, 2000: 55). However, research shows that politicians rarely do either of these two things on social media. They neither use social networks to inform citizens of their policies, nor do they communicate personal information which would allow voters to get a better understanding of who they 'really' are (Larsson, 2015; Momoc, 2013; Ross et al., 2015).

It is argued that communication on social media should be less fabricated, more natural, personal and 'colloquial'. Formal communication styles usually result in politicians being criticised for not being able to adapt to the social network conventions and to communicate in a more informal, relaxed way (Savulescu and Vitelar, 2012; Zamora Medina and Zurutuza Munoz, 2014). Hence, politicians may speak in colloquial language in order to connect with voters in a language which the voters themselves find appropriate and easy to understand, and in doing so, portray themselves as 'one of the people' (Grbeša, 2008; Holtz-Bacha, 2004).

\section{RESEARCH DESIGN}

\section{Study Context}

This study is focused on the Republic of Croatia, a young Central Eastern European democracy and a Member State of the European Union. Croatia is a parliamentary democracy with dual leadership. Alongside the Prime Minister, who is the head of the government, is the President of the Republic who also has some, although very limited, executive powers. There are several reasons for examining the Croatian case. Research has shown that the use of social networks for political communication, particularly Facebook, can have more value in new, as compared to old, EU member states (Lilleker et al., 2015: 756-7). In addition, the electoral system used in the presidential elections is a majorityrunoff system, meaning that voters cast a single vote for the chosen candidate, therefore making social media a great tool for candidates wishing to get closer to those they wish to represent. 
A further reason for why it is important to examine how, if at all, politicians in Croatia use social media to reach, engage and bond with voters, is because of the generally low level of political engagement of Croatian citizens. At the time of the 2014/2015 presidential elections, the majority of Croatian citizens eligible to vote did not use this constitutional right, and had not done so since the parliamentary elections in 2011. Specifically, voter turnout in the 2013 local elections was $46.97 \%$, whilst the turnout in the 2014 European Parliament elections was $25.24 \%$, only Slovakia, Poland and the Czech Republic had less voters attending polling stations (Ukpolitical.info, n.d.). Of these EU Member States with the lowest turnouts in the 2014 EP elections, Croatian citizens at the time expressed the lowest level of trust in their national government. This was recorded at $16 \%$, and other political institutions did not fare any better (with only $18 \%$ of citizens saying that they had trust in parliament, and only $10 \%$ expressing trust in political parties) (European Commission, 2014).

Although Croatia has less regular internet users than many other EU Member States, recorded at $66 \%$, digital media - and particularly social networks - seem to be widely used (Digital Economy and Society Index, 2016). Specifically, $89 \%$ of Croatians consume online news, and $64 \%$ use social media, which is in line with the EU-28 average (Ibid.).

As far as the social context of the research is concerned, Dražen Lalić and Marijana Grbeša (2015) describe it as unfavourable for the incumbent Ivo Josipović, primarily due to the ongoing six years of economic crisis at the time. The crisis was the result of both the HDZ's (Croatian Democratic Union) and the SDP (Social Democratic Party of Croatia) administration's failures in conducting reforms. "However, the failure to introduce the required reforms has for the most part been blamed on the SDP"1 (Lalić and Grbeša, 2015: 47). Furthermore, the presidential election was held in an atmosphere of political clashes, mostly related to ideological issues. Therefore, as Lalić and Grbeša (2015) conclude, the presidential election was a competition between the incumbent Josipović and his three challengers: the moderate conservative HDZ's - Kolinda Grabar-Kitarović, the rebellious leader of the Human Wall - Ivan Vilibor Sinčić, and Milan Kujundžić, the candidate of the rigid right-wing coalition led by the Croatian Dawn - The Party of the People.

\section{Methodology}

To fulfil the research goal, a content analysis of all statements published on the official Facebook and Twitter profiles of the presidential candidates was conducted. ${ }^{2}$ Content analysis allows researchers to detect trends and patterns in text (Berger, 2011; Deacon, 2007), which makes it the most suitable method within the context of the research goal. In addition, content analysis has been used in similar, earlier studies (e.g. Larsson, 2015; Ross et al., 2015).

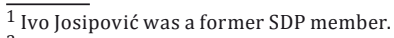

2 The results presented here are the part of a bigger research project that included a content analysis of statements that presidential candidates published on their social media accounts, as well as mediated statements in the newspaper. This research examines the ways in which presidential candidates utilise social media tools in their election campaigns to democratise politics and political representation, whilst similarities and differences between direct and mediated political candidates' communication during electoral campaigns, and techniques of impression management employed in their direct and mediated communication, are presented in another paper.
} 
The start date for the analysis was the first day of the official campaign in the 2014 presidential elections (9 December 2014) and ended the day before the second round of elections (9 January 2015). The sample consisted of all Facebook posts and Tweets that were published by candidates on their official profiles during the campaign. The unit of analysis is a statement, which is defined as the totality of words within a social media post that can be identified as having been written by a candidate.

In total, 391 statements were published by the presidential candidates, with 231 published via Facebook and 160 via Twitter, i.e. incumbent Ivo Josipović (IJ), main challenger Kolinda Grabar-Kitarović (KGK), political activist Ivan Vilibor Sinčić (IVS), and Milan Kujundžić (MK) were analysed. Statements made by Sinčić and Kujundžić were analysed only until $28^{\text {th }}$ December 2014 , since they did not progress into the second round of elections.

A set of analysed variables, representing candidates' utilisation of social media, has been drawn from the literature (Larsson, 2015; Zamora Medina and Zurutuza Munoz, 2014; Savulescu and Vitelar, 2012; Ross et al., 2015) and includes photograph/links/video attachments, questions posed, calls for participation in an action or activity, sharing others' posts or tweets, participating in the discussion following the statement, and using tools such as hashtag and tagged names on Facebook. Candidates' private profile, as well as the definition of colloquial and first person language, were defined following previous similar studies that examined the visibility of political candidates' private lives in public discourses and their use of language (Brečić et al., 2012; Grbeša, 2004),

Inter-coder reliability was calculated on a sample of 39 randomly chosen statements, representing $10 \%$ of the sample. The average reliability score calculated using Holsti's method of agreement across all categories was 0.91 .

\section{FINDINGS}

The analysis suggests that candidates in the 2015 Croatian presidential elections considered social media as a channel for communication with voters. The incumbent Ivo Josipović (IJ) was the most active on social networks, publishing a total of 194 statements during the campaign. His main challenger, Kolinda Grabar-Kitarović (KGK), published 89, Milan Kujundžić (MK) 66, while Ivan Vilibor Sinčić (IVS), also the only one who, perhaps surprisingly, did not have a Twitter account, published only 42 statements on social networks. However, candidates used social media mainly to strengthen their campaigns rather than as a real space for democratising politics and political representation. There is limited evidence to suggest that presidential candidates used social media to reach, engage or bond with voters. 


\section{Reaching Voters}

The data shows that only one candidate, Grabar-Kitarović, partly recognised the opportunity to reach voters by using hashtags and/or tagged accounts. While Josipović and Kujundžić sporadically used this technique, its occasional use does not suggest that its real potential was exploited. Sinčić did not used this technique at all. Whilst the use of hashtags/tagged accounts was at least sporadically used, no candidate tapped into the potential of others' networks to reach potential voters, since there is limited evidence of sharing others' content. Candidates did not seem to attempt to help citizens hear their arguments, and consequently, make better informed decisions with regards to voting (Table 1).

Table 1. Techniques for reaching voters (\% of statements)

\begin{tabular}{lllll} 
Techniques for reaching voters & Author & & & \\
& KGK & IJ & IVS & MK \\
used hashtag or tagged account & 45 & 28 & 0 & 22 \\
shared others' content & 1 & 1 & 2 & 0 \\
\hline
\end{tabular}

\section{Engaging Voters}

There is some evidence to suggest that candidates tried to engage voters. All candidates attached materials to their statements on social media, with three out of four doing this regularly. This may be due to the understanding that multimedia content increases users' engagement on social media.

Table 2. Techniques for engaging voters (\% of statements)

\begin{tabular}{llllll}
\hline Techniques for engaging voters & Author & & & \\
& KGK & IJ & IVS & MK \\
invited followers to participate in an activity & 28 & $\mathbf{5 2}$ & 17 & $\mathbf{8 0}$ \\
posed questions & 6 & 10 & 7 & 11 \\
participated in discussion following a statement & 2 & 3 & 14 & 2 \\
attached multimedia materials & $\mathbf{7 6}$ & $\mathbf{7 8}$ & $\mathbf{3 8}$ & $\mathbf{7 4}$ \\
\hline
\end{tabular}

Incumbent Josipović and the right-wing candidate Kujundžić also made an attempt to use social media to increase followers' participation in the democratic process, by inviting them to participate in a, usually, campaign-related activity. However, both of these techniques can still be seen as quite one-sided on the part of the politicians, since they do not really require voters' engagement. This deliberative potential of social media, through which politicians can invite voters to participate in public debates by posing questions and debating them in the comments section, was not exploited. The data shows that candidates rarely posed interesting questions or participated in discussions following 
their statements on social media. Hence, the results suggest that Croatian presidential candidates did not use the full potential of social media to establish an interactive and multi-directional dialogue with their voters, nor were they willing to tap into this potential, and they did not understand that social media can be a powerful tool for mobilising voters (Table 2).

\section{Creating Bonds with Voters}

According to the analysis, topics about the campaign ranked first in all candidates' statements, while insights into politicians' private lives were almost non-existent (Table 3). This demonstrates the fact that politicians failed to use social media to communicate their political messages without intermediaries, as well as to reveal information that works to supplement their political profile. This proves that political actors' Facebook activity can mostly be described as 'politics as usual' (e.g. Margolis and Resnick, 2000), and served as preparation for other, mostly 'offline' political events and activities (Larsson, 2016).

Table 3. Focus of the statements (\% of statements)

\begin{tabular}{lllll}
\hline Focus of the statement & Author & & & \\
& KGK & IJ & IVS & MK \\
\hline Current socio-political issues & 6 & 3 & 0 & 2 \\
Campaign & 73 & 68 & 93 & 94 \\
Elections & 4 & 0 & 0 & 0 \\
Presidential function & 8 & 25 & 0 & 0 \\
Attacking present authorities & 4 & 1 & 0 & 2 \\
Attacking opponents & 4 & 2 & 5 & 2 \\
Private profile & 1 & 1 & 0 & 0 \\
Other & 0 & 0 & 2 & 0 \\
\hline
\end{tabular}

Looking more closely at candidates' statements, there is no evidence to suggest that they even sporadically shared their personal information i.e. mentioning private matters, but not as the focus of the statements. Candidates did not communicate information about their families, family life, lifestyle, hobbies, interests, etc. that may have helped them in creating bonds with voters.

Finally, the study also shows that none of the candidates communicated in a relaxed tone (colloquial language was used in only $2 \%$ of Grabar-Kitarović's statements, $8 \%$ of Josipović's, $10 \%$ of Sinčić's, and $17 \%$ of Kujundžić's) (Table 4). In addition, only Josipović partly communicated in first person ( $45 \%$ ), while other candidates used mainly impersonal language (first person was used in $28 \%$ of Grabar-Kitarović's statements, $5 \%$ of Sinčićs, and $2 \%$ of Kujundžić's). 
Table 4. Usage of colloquial language (\% of statements)

\begin{tabular}{|c|c|c|c|}
\hline \multicolumn{2}{|c|}{ Usage of colloquial language } & \multirow{2}{*}{$\begin{array}{l}\text { Yes } \\
2\end{array}$} & \multirow{2}{*}{$\begin{array}{l}\text { No } \\
98\end{array}$} \\
\hline Author & KGK & & \\
\hline & IJ & 8 & 92 \\
\hline & IVS & 10 & 90 \\
\hline & MK & 17 & 83 \\
\hline
\end{tabular}

\section{DISCUSSION AND CONCLUSIONS}

The inquiry into how presidential candidates in the 2014/2015 Croatian elections used social media has revealed that the candidates made almost no attempt at reaching voters, engaging them and creating bonds with them. In addition, the candidates also failed to communicate relevant information about their programmes and issues, and ultimately it appears they used social media as bulletins for campaign information. As a result, in the context of low voter turnout, low political mobilisation, and a high distrust towards political institutions, there is little evidence to suggest that politicians make use of social media to democratise politics and representation through social media.

The Croatian case shows that presidential candidates made little attempt at reaching voters on social media, enabling them to hear more (alternative) political arguments, and thus helping them make informed decisions about who to vote for (Gustafsson, 2012). This finding once again demonstrates that there is a gap between what politicians and their campaign strategists claim they use social media for (Lilleker et al., 2015; Serazio, 2014) and what they actually do on social media in the most important political periods. Even if the 'echo chamber'/'filter bubble' phenomenon (Bozdag and van den Hoven, 2015; Flaxman et al., 2016) is relevant in the Croatian context, and social media users are somewhat ideologically segregated (establishing this was beyond the scope of this study), political candidates showed very limited attempts at creating content that might 'break the bubble' and help them reach citizens beyond those already interested in what they have to say.

Presidential candidates made only seeming attempts at prompting the engagement of their voters on social media. They did not mobilise voters by asking for their feedback and opinions, and they did not engage in discussions with them. By doing this they failed to use the potential of social media to democratise politics and political representation (Coleman, 2005; Sørensen, 2016), revitalise the public sphere (Jensen, 2011; Papacharissi, 2002), and ultimately increase voters' political participation, the outcome of which could be an increase in the legitimacy of the country's political processes and elected representatives. Although some politicians claim that they use social media because of its potential for two-way communication (e.g. Enli and Skogerbø, 2013), this analysis reinforces previous findings that politicians use social media as a one-way channel of communication to, rather than with, voters (e.g. Larsson, 2015; Macnamara and Kenning, 
2011, 2013; Momoc, 2013; Nielsen, 2011; Ross et al., 2015; Zamora Medina and Zurutuza Munoz, 2014). Consequently, in line with Sørensen's (2016) conclusion, there remains limited evidence that dialogic political communication is taking place on social media.

Finally, this study has revealed that politicians in 2014/2015 made no attempts at creating bonds with voters by communicating personal information, which is considered a necessary communication technique on social media (Enli and Skogerbø, 2013; Larsson, 2015; Savulescu and Vitelar, 2012; Zamora Medina and Zurutuza Munoz, 2014). In doing so, they have missed an opportunity to express and promote their political views and programmes through an unobstructed channel of communication. Perhaps one of the reasons for this is similar to that found by Graeme Baxter and colleagues (2013) who suggest that social media is not always well-suited for communicating policy information and commentary, due to some of its restrictions e.g. Twitter's 140-character restriction). However, perhaps a more likely explanation is that political actors continue to see social media as a low-cost public relations vehicle that serves as an alternative to expensive forms of campaign communication and promotion (Baxter et al., 2016; Obholzer and Daniel, 2016). This is in line with Stromer-Galley's recent argument that "campaigns wish to mobilise the public in the service of the campaign, but getting too close to them, really listening and empowering them, is dangerous or at least disadvantageous" (StromerGalley, 2014: 187). She, furthermore, points out that interactivity is what a healthy democracy requires" (Stromer-Galley, 2014: 187).

Overall, this study proves what was suggested previously by many authors (e.g. Larsson, 2015; Momoc, 2013; Ross et al., 2015; Zamora Medina and Zurutuza Munoz, 2014), that political candidates see social media as a public relations vehicle for informing their followers of campaign events, whilst the potential of social media to democratise and revitalise politics, representation in the public sphere, remains largely untapped. Political elites, including the candidates, view the internet, in the words of Graeme Browning (2002, in Stromer-Galley, 2014: 177), as "little more than a big electronic auditorium where millions of people gather to spout off much like high-school kids in a civics class- but nonetheless have little impact on the crafting of policies that govern them." (Ibid.)

The theoretical contribution of this paper is in the proposed concept based on the utilisation of social media for reaching, engaging and creating bonds with voters. At the end, it can consequently increase the legitimacy of democratic processes and elected representatives.

Given the limitations of the sample, as well as the fact that political cultures have national characteristics, it is not possible to generalise the results beyond the Croatian context. In addition, due to the limitations of the method, it was not possible to examine the reasons for specific politicians' social media usage, nor the effects that their social media had on voters. Both of these limitations, however, can be seen as possible avenues for future research. It would be interesting to further develop this study by comparing politicians' utilisation of social media across Central Eastern Europe and within other 
similar contexts. Moreover, it would be interesting to examine how voters utilise the political information available on social media within this context. and what voters' expectations are with regards to online communication with politicians.

\section{References}

>Ahmed, Saifuddin; Jaidka, Kokil and Cho, Jaeho (2016) The 2014 Indian Elections on Twitter: A Comparison of Campaign Strategies of Political Parties. Telematics and Informatics 33 (4): 1071-1087. DOI: 10.1016/j.tele.2016.03.002.

>Baxter, Graeme and Marcella, Rita (2012) Does Scotland 'Like' This? Social Media Use by Political Parties and Candidates in Scotland During the 2010 UK General Election Campaign. Libri 62 (2): 109124. DOI: 10.1515/libri-2012-0008.

>Baxter, Graeme; Marcella, Rita; Chapman, Denis and Fraser, Alan (2013) Voters' Information Behaviour when Using Political Actors' Web Sites During the 2011 Scottish Parliament Election Campaign. Aslib Proceedings 65 (5): 515-533. DOI: 10.1108/AP-09-2012-0073.

>Baxter, Graeme; Marcella, Rita and O'Shea, Mary (2016) Members of the Scottish Parliament on Twitter: Good Constituency Men (and Women)? Aslib Journal of Information Management 68 (4): 428-447. DOI: 10.1108/AJIM-02-2016-0010.

$>$ Bene, Marton (2017) Sharing is Caring! Investigating Viral Posts on Politicians' Facebook Pages During the 2014 General Election Campaign in Hungary. Journal of Information Technology \& Politics. http://www.tandfonline.com/doi/abs/10.1080/19331681.2017.1367348. (26.09.2017). DOI: 10.1080/19331681.2017.1367348.

>Berger, Arthur Asa (2011) Media and Communication Research Methods: An Introduction to Qualitative and Quantitative Approaches. London: Sage publications.

>Blog.twitter.com (2015) Twitter Business Outlook. https://blog.twitter.com/2015/tweettip-usephotos-to-drive-engagement. (18.11.2016).

>Bozdag, Eengin and van den Hoven, Jeroen (2015) Breaking the Filter Bubble: Democracy and Design. Ethics and Information Technology 17 (4): 249-265. DOI: 10.1007/s10676-015-9380-y. >Brečić, Katarina; Milanović, Lana and Šimunjak, Maja (2012) „Amerikanizacija“ bez trivijalizacije: Analiza novinskog izvještavanja o predizbornoj kampanji Vesne Pusić 2009. godine ("Americanization" Without Trivialization: Analysis of Newspaper Reporting about Vesna Pusić's 2009 Presidential Campaign). Društvena istraživanja 21 (2): 523-44. DOI: 10.5559/di.21.2.12. $>$ Bruns, Axel and Highfield, Tim (2013) Political Networks on Twitter: Tweeting the Queensland State Election. Information, Communication and Society 16 (5): 667-691. DOI: 10.1080/1369118X.2013.782328.

$>$ Carlisle, Juliet and Patton, Robert (2013) Is Social Media Changing How We Understand Political Engagement? An Analysis of Facebook and the 2008 Presidential Election. Political Research Quarterly 20 (10): 1-13. DOI: 10.1177/1065912913482758.

$>$ Coleman, Stephen (2005) New Mediation and Direct Representation: Reconceptualizing Representation in the Digital Age. New Media \& Society 7 (2): 177-198. DOI:

$10.1177 / 1461444805050745$.

>Deacon, David (2007) Researching Communications: A Practical Guide to Methods in Media and Cultural Analysis. London: Hodder Arnold.

>Digital Economy and Society Index (2016) Country profile: Croatia. http://ec.europa.eu/newsroom/ dae/document.cfm?action=display\&doc_id=14142. (19.11.2016).

>Enli, Gunn Sara and Skogerbø, Eli (2013) Personalized Campaigns in Party-Centred Politics: Twitter and Facebook as Arenas for Political Communication. Information, Communication \& Society 16 (5): 757-774. DOI: 10.1080/1369118X.2013.782330.

>Enli, Gunn Sara and Thumim, Nancy (2012) Socializing and Self-Representation Online: Exploring Facebook. Observatorio (OBS*) 6 (1): 87-105. 
>European Commission (2014) Public Opinion in the European Union. Standard Eurobarometer 82. http://ec.europa.eu/public_opinion/archives/eb/eb82/eb82_publ_en.pdf. (18.11.2016). >Flaxman, Seth; Goel, Sharad and Rao, Justin (2016) Filter Bubbles, Echo Chambers, and Online News Consumption. Public Opinion Quarterly 80 (Special Issue): 298-320. DOI: 10.1093/poq/nfw006. Gibson, Rachel (2015) Party Change, Social Media and the Rise of 'Citizen Initiated' Campaigning. Party politics 21 (2): 183-197. DOI: 10.1177/1354068812472575.

$>$ Graham, Tod; Broersma, Marcel; Hazelhoff, Karin and van't Haar, Guido (2013) Between Broadcasting Political Messages and Interacting with Voters: The Use of Twitter During the 2010 UK General Election Campaign. Information, Communication and Society 16 (5): 692-716. DOI: 10.1080/1369118X.2013.785581.

> Grbeša, Marijana (2008) Personality Politics in Croatia: An Inquiry into Election Campaigns, Media Coverage and Public Perception in the 2003 and 2007 Parliamentary Elections. Doctoral Dissertation. University of Ljubljana, Faculty of Social Sciences.

>Grbeša, Marijana (2004) Personalization in Croatian Presidential Election in 2000: How Personal Did the Candidates Go and What Did the Press Cover? Politička Misao 41 (5): 52-73.

$>$ Groshek, Jacob and Koc-Michalska, Karolina (2017) Helping Populism Win? Social Media Use, Filter Bubbles, and Support for Populist Presidential Candidates in the 2016 US Election Campaign, Information, Communication \& Society 34 (1): 1-5. 1389-1407. DOI: 10.1080/1369118X.2017.1329334. $>$ Gustafsson, Nils (2012) The Subtle Nature of Facebook Politics: Swedish Social Network Site Users and Political Participation. New Media \& Society 14 (7): 1111-1127. DOI: 10.1177/1461444812439551. $>$ Holtz-Bacha, Christina (2004) Germany: How the Private Life of Politicians Got into the Media. Parliamentary Affairs 57 (1): 41-52. DOI: 10.1093/pa/gsh004.

>Hong, Sounman and Nadler, Daniel (2012) Which Candidates Do the Public Discuss Online in an Election Campaign?: The Use of Social Media by 2012 Presidential Candidates and its Impact on Candidate Salience. Government Information Quarterly 29 (4): 455-461. DOI: 10.1016/j. giq.2012.06.004.

>Jensen, Jakob Linaa (2011) Citizenship in the Digital Age: The Case of Denmark. Policy \& Internet 3 (1): 1-22. DOI: 10.2202/1944-2866.1106.

>Jungherr, Andreas (2012) The German Federal Election of 2009: The Challenge of Participatory Cultures. Transformative Works and Cultures. http://journal.transformativeworks.org/index.php/twc/ article/view/310/288 (15.02.2016). DOI: 10.3983/twc.2012.0310.

>Kalsnes, Bente; Krumsvik, Arne and Storsul, Tanja (2014) Social Media as a Political Backchannel. Aslib Journal of Information Management 66 (3): 313-28. DOI: 10.1108/AJIM-09-2013-0093. >Lalić, Dražen and Grbeša, Marijana (2015) The 2014/2015 Croatian Presidential Election: Tight and Far-reaching Victory of the Political Right. Contemporary Southeastern Europe 2 (1): 45-54. $>$ Larsson, Anders Olof (2016) Online, all the time? A quantitative Assessment of the Permanent Campaign on Facebook. New media \& society 18 (2): 274-292. DOI: 10.1177/1461444814538798. $>$ Larsson, Anders Olof (2015) Pandering, Protesting, Engaging. Norwegian Party Leaders on Facebook During the 2013 'Short Campaign'. Information, Communication \& Society 18 (4): 459-473. DOI: 10.1080/1369118X.2014.967269.

>Larsson, Anders Olof and Moe, Hallvard (2013) Representation or Participation? Twitter Use During the 2011 Danish Election Campaign. Javnost-The Public 20 (1): 71-88. DOI: 10.1080/13183222.2013.11009109.

>Larsson, Anders Olof and Moe, Hallvard (2012) Studying Political Microblogging: Twitter Users in the 2010 Swedish Election Campaign. New Media \& Society 14 (5): 729-747. DOI: 10.1177/1461444811422894.

>Lilleker, Darren G., Pack, Mark and Jackson, Nigel (2010) Political Parties and Web 2.0: The Liberal Democrat Perspective. Politics 30 (2): 105-112. DOI: 10.1111/j.1467-9256.2010.01373.x. >Lilleker, Darren; Tenscher, Jens and Štětka, Václav (2015) Towards Hypermedia Campaigning? Perceptions of New Media's Importance for Campaigning by Party Strategists in Comparative Perspective. Information, Communication \& Society 18 (7): 747-65. DOI: 10.1080/1369118X.2014.993679. 
>Macnamara, Jim and Kenning, Gail (2013) E-electioneering 2013: An Analysis of the Use of Social Media and Online Communication in the 2013 Australian Federal Election and Comparison with the 2007 and 2010 Elections. Sydney: Australian Centre for Public Communication, University of Technology Sydney.

>Macnamara, Jim and Kenning, Gail (2011) E-electioneering 2010: Trends in Social Media Use in Australian Political Communication. Media International Australia 139 (1): 7-22. DOI: 10.1177/1329878x1113900104.

>Margolis, Michael and Resnick, David (2000) Politics as Usual: The Cyberspace Revolution. Thousand Oaks: Sage Publications. DOI: 10.4135/9781452233475.

>Momoc, Antonio (2013) Social Media-PR Tools for Romanian Politicians? Procedia-Social and Behavioral Sciences 81: 116-121. DOI: 10.1016/j.sbspro.2013.06.398.

$>$ Murthy, Dhiraj and Petto, Laura (2015) Comparing Print Coverage and Tweets in Elections, A Case Study of the 2011-2012 U.S. Republican Primaries. Social Science Computer Review 33 (3): 298-314. DOI: $10.1177 / 0894439314541925$.

>Nielsen, Rasmus Kleis (2011) Mundane Internet Tools, Mobilizing Practices, and the Coproduction of Citizenship. New Media \& Society 13 (5): 755-771. DOI: 10.1177/1461444810380863.

$>$ Nielsen, Rasmus Kleis and Vaccari, Cristian (2013) Do People "Like" Politicians on Facebook? Not Really. Large-scale Direct Candidate-to-Voter Online Communication as an Outlier Phenomenon. International Journal of Communication 7: 2333-2356.

$>$ Obholzer, Lukas and Daniel, William T. (2016) An Online Electoral Connection? How Electoral Systems Condition Representatives' Social Media Use. European Union Politics 17 (3): 387-407. DOI: $10.1177 / 1465116516630149$.

>Papacharissi, Zizi (2002) The Virtual Sphere the Internet as a Public Sphere. New Media \& Society 4 (1): 9-27. DOI: $10.1177 / 14614440222226244$.

$>$ Park, Se Jung; Park, Ji Young; Lim, Yon Soo and Park, Han Woo (2016) Expanding the Presidential Debate by Tweeting: The 2012 Presidential Election Debate in South Korea. Telematics and Informatics 33 (2): 557-569. DOI: 10.1016/j.tele.2015.08.004.

$>$ Ross, Karen and Bürger, Tobias (2014) Face to Face(book): Social Media, Political

Campaigning and the Unbearable Lightness of Being There. Political Science 66 (1): 46-62. DOI: $10.1177 / 0032318714534106$.

$>$ Ross, Karen; Fountaine, Susan and Comrie, Margie (2015) Facing up to Facebook: Politicians, Publics and the Social Media (Ted) Turn in New Zealand. Media, Culture \& Society 37 (2): 251-269. DOI: $10.1177 / 0163443714557983$.

>Savulescu, Rodica and Vitelar, Alexandra (2012) Pics or It Didn't Happen: Analyzing Facebook Photographs of Romanian Women Politicians. Romanian Journal of Communication and Public Relations 14 (1): 7-20.

>Serazio, Michael (2014) The New Media Designs of Political Consultants: Campaign Production in a Fragmented Era. Journal of Communication 64 (4): 743-763. DOI: 10.1111/jcom.12078.

>Sørensen, Mads P. (2016) Political Conversations on Facebook - the Participation of Politicians and Citizens. Media, Culture \& Society 38 (5): 664-685. DOI: 10.1177/0163443715620924.

>Spohr, Dominic (2017) Fake News and Ideological Polarization: Filter bubbles and

Selective Exposure on Social Media. Business Information Review 34 (3): 150-160. DOI: $10.1177 / 0266382117722446$.

>Strandberg, Kim (2013) A Social Media Revolution or just a Case of History Repeating Itself? The Use of Social Media in the 2011 Finnish Parliamentary Elections. New Media \& Society 15 (8): 13291347. DOI: $10.1177 / 1461444812470612$.

>Stromer-Galley, Jennifer (2014) Presidential Campaigning in the Internet Age. Oxford: Oxford University Press. DOI: 10.1093/acprof:0so/9780199731930.001.0001.

$>$ Sweetser, Kaye D. and Lariscy, Ruthann Weaver (2008) Candidates Make Good Friends: an Analysis of Candidates' Uses of Facebook. International Journal of Strategic Communication 2 (3): 175-198. DOI: 10.1080/15531180802178687. 
$>$ Ukpolitical.info (n.d.) European Parliament Election Turnout. http://www.ukpolitical.info/europeanparliament-election-turnout.htm. (18.11.2016).

$>$ Utz, Sonja (2009) The (Potential) Benefits of Campaigning via Social Network Sites. Journal of Computer-Mediated Communication 14 (2): 221-243. DOI: 10.1111/j.1083-6101.2009.01438.x. $>$ Vaccari, Cristian; Valeriani, Augusto; Barberá, Pablo; Bonneau, Rich; Jost, John; Nagler, Jonathan and Tucker, Joshua (2013) Social Media and Political Communication: A Survey of Twitter Users during the 2013 Italian General Election. Rivista Italiana di Scienza Politica 43 (3): 381-410. DOI: $10.1426 / 75245$.

$>$ Van Zoonen, Liesbet and Holtz-Bacha, Christina (2000) Personalisation in Dutch and German Politics: the Case of Talk Show. Javnost - The Public 7 (2): 45-56. DOI: 10.1080/13183222.2000.11008743.

>Vučković, Milica and Bebić, Domagoj (2013) Facebook Usage by Mayors in Central and Southeastern Europe. Medijske studije 4 (8): 32-44.

>Zamora Medina, Rocio and Zurutuza Munoz, Cristina (2014) Campaigning on Twitter: Towards the 'Personal Style' Campaign to Activate the Political Engagement During the 2011 Spanish General Elections. Communication \& Society / Comunicación y Sociedad 27 (1): 83-106. 


\section{DOSEZANJE I UKLJUČIVANJE BIRAČA TE POVEZIVANJE S BIRAČIMA PUTEM DRUŠTVENIH MREŽA: ANALIZA PREDSJEDNIČKIH IZBORA U REPUBLICI HRVATSKOJ 2014./2015. GODINE}

\section{Dubravka Sinčić Ćorić :: Ružica Brečić :: Maja Šimunjak}

SAŽETAK U radu se istražuje koriste li i na koji način predsjednički kandidati društvene mreže kako bi demokratizirali politiku i političko predstavljanje. Studija prikazuje rezultate analize sadržaja izjava koje su predsjednički kandidati objavili na svojim službenim profilima na Facebooku i korisničkim računima na Twitteru tijekom izborne kampanje u Republici Hrvatskoj 2014./2015. Rezultati otkrivaju da kandidati nisu koristili društvene mreže kako bi dosegli i uključili potencijalne birače, niti su ih koristili kako bi s biračima ostvarili jaču emotivnu vezu. Propuštajući ovu priliku, propustili su i mogućnost privlačenja nezadovoljnih i razočaranih birača na birališta, čime se mogao povećati i legitimitet demokratskog procesa.

KLJUČNE RIJEČI

DRUŠTVENE MREŽE, POLITIČKA KAMPANJA, PREDSJEDNIČKI IZBORI, DEMOKRATIZACIJA POLITIKE

Bilješka o autoricama

Dubravka Sinčić Ćorić :: Sveučilište u Zagrebu, Ekonomski fakultet :: dsincic@efzg.hr Ružica Brečić :: Sveučilište u Zagrebu, Ekonomski fakultet :: rbrecic@efzg.hr Maja Šimunjak :: Middlesex University London, Faculty of Arts and Creative Industries, Ujedinjeno Kraljevstvo :: m.simunjak@mdx.ac.uk 